\title{
THE BREEDING AND ECONOMIC VALUES OF RELATED LEADER 1926780 GROUP BULLS IN UKRAINIAN RED AND WHITE DAIRY BREED
}

\author{
A. P. KRUGLIAK ${ }^{1}$, O. D. BIRUKOVA ${ }^{1}$, T. O. KRUGLIAK ${ }^{\mathbf{1}}$, O. V. KRUGLIAK ${ }^{\mathbf{1}}$, \\ N. H. CHERNIAK ${ }^{1}$, Ya. V. STOLIAR ${ }^{2}$, D. V. POLISHCHUK \\ ${ }^{1}$ Institute of Animal Breeding and Genetics nd. a. M. V.Zubets NAAS (Chubynske, Ukraine) \\ ${ }^{2}$ Institute of feed research and agriculture Podillya NAAS (Vinnytsia, Ukraine) \\ ${ }^{3}$ Zhytomyr national agroecological university (Zhytomyr, Ukraine) \\ bulochka23@ukr.net
}

The resalts of breeding and economic value of related group Leader 1926780 bulls, which are used in Ukrainian red and white dairy breed of cattle are given an account. It has been determined, that the bulls of this group keep the breeding value at complex of milk produktivity traits on high level during 8-11 years and well transfer these traits by inheritance to the native offspring. According to the number of animals, genealogical structure, level of the influence to the breed s consolidation, it is possible use wide this group of bulls in the breeding herds of the Ukrainian red and white dairy breed and to create new bloodline with high content protein and fat in milk.

Keywords: related group, breeding value, foreign selection, consolidation of breed, economic effectiveness

\section{ПЛЕМІННА І ГОСПОДАРСЬКА ЦІННІСТЬ БУГАЇВ СПОРІДНЕНОЇ ГРУПИ ЛІДЕРА 1926780 В УКРАЇНСБКІЙ ЧЕРВОНО-РЯБІЙ МОЛОЧНІЙ ПОРОДІ}

А. П. Кругляк ${ }^{1}$, О. Д. Бірюкова ${ }^{1}$, Т. О. Кругляк ${ }^{1}$, О. В. Кругляк ${ }^{1}$, Н. Г. Черняк ${ }^{1}$, Ж. В. Столяр ${ }^{2}$, Д. В. Полищук ${ }^{3}$

${ }^{1}$ Інститут розведення і генетики тварин імені М.В.Зубия НААН (Чубинське, Україна)

${ }^{2}$ Інститут кормів та сільського господарства Поділля НААН (Вінниия, Україна)

ЗЖитомирський національний агроекологічний університет (Житомир, Україна)

Викладено результати досліджень племінної та господарської цінності бугаӥв-поліпшувачів комплексу ознак спорідненої групи Лідера 1926780, які використовуються у племінних стадах української червоно-рябої молочної породи. Встановлено, щчо бугаї зарубіжної селекиї иісї спорідненої групи, при використанні в племінних стадах зберігають племінну иінність за комплексом ознак на додатному рівні протягом 8-11 років та стійко передають ї̈ потомкам вітчизняної селекиії. За чисельністю поголів'я, генеалогічною структурою, рівнем впливу на консолідацію породи за комплексом ознак молочної продуктивності (надій, вміст жиру та білка в молоиі) тварини ичієї спорідненої групи заслуговують на широке використання у племінних підприємствах УЧРМ породи та створення на їхній основі загальнопородної заводської високо білково-жирномолочної лінії.

Ключові слова: споріднена група, племінна цінність, зарубіжна селекція, консолідація породи, економічна ефективність

\section{ПЛЕМЕННАЯ И ХОЗЯЙСТВЕННАЯ ЦЕННОСТЬ БЫКОВ РОДСТВЕННОЙ ГРУППЫ ЛИДЕРА 1926780 В УКРАИНСКОЙ КРАСНО-ПЕСТРОЙ МОЛОЧНОЙ ПОРОДЕ}
А. П. Кругляк ${ }^{1}$,
О. Д. Бирюкова ${ }^{1}$,
Т. А. Кругляк ${ }^{1}$,
О. В. Кругляк ${ }^{1}$,
Н. Г. Черняк ${ }^{1}$, Ж. В. Столяр ${ }^{2}$, Д. В. Полищук ${ }^{3}$
${ }^{1}$ Институт разведения и генетики животных имени М.В.Зубиа НААН (Чубинское, Украина)
${ }^{2}$ Институт кормов и сельского хозяйства Подолья НААН (Винница, Украина)
${ }^{3}$ Житомирский начиональный агроекологический университет (Житомир, Украина) 
Изложены результаты исследований племенной и хозяйственной ценности быковулучшателей комплекса признаков родственной группь Лидера 1926780, которые используются в племенных стадах украинской красно-пестрой молочной породы. Установлено, что быки зарубежной селекиии этой родственной группь, при использовании в племенных стадах сохраняют племенную иченность комплекса признаков на позитивном уровне в течении 8-11 лет и стойко передают ее потомкам отечественной селекции. По численности поголовья, генеалогической структуре, уровню влияния на консолидацию породы по комплексу признаков молочной продуктивности (удой, содержание жира и белка в молоке) животных этой родственной группь можно широко использовать в племенных предприятиях украинской краснопестрой молочной породы и, на их основе, создать общепородную заводскую високо белковожирномолочную линию.

Ключевые слова: родственная группа, племенная ценность, зарубежная селекция, консолидация породы, экономическая эффективность

Introduction. Breeding of farm animals according to the bloodlines in the conditions of largescale selection remains a significant component of the modern theory of breed as for pure breeding so, one of the main methods, for improving domestic breeds of cattle. The bloodlines are recognized as obligatory structural units, through which the genetic progress of the breed in general is ensured [1-3]. At present stage, selection of the Ukrainian red and white dairy breed takes aim at the stabilizing and improving the quality traits of milk productivity (fat and protein content in milk), the type of body structure, reproductive capacity and the duration of economic use of animals, which will ensure the economic efficiency of their breeding [4]. In this connection, the creation of specialized dairy groups of animals with high content protein and fat in milk and extended duration of economic use becomes actual.

The purpose of our work was to determine the dynamics of breeding and economic values of bulls of a related Leader 1926780 group, in the process of their use in breeding at the stage of consolidation of the Ukrainian red and white dairy breed.

Materials and methods. To assess the influence of the use of this group of bulls (a related of the Leader group 1926780) on the level and quality of milk productivity in the herds of the Ukrainian red and white dairy breed, the dynamics of the breeding and economic values of 13 bulls of the Holstein breed and 8 domestic selection of this related group with different part of parental blood, throughout the period of their use, on the basis of the Catalog (Besamungsbullen) and the Catalog of bullen dairy and dairy-beef breeds for reproduction of livestock in 2004-2016 years were studied. The research was carried out on the basis of the materials of the primary breeding records at the breeding enterprises of "Genetic Resources», «The Ukrainian Genetic Company», "The Main Selection Center», «Poltavapleservis», and in the herds of the leading breeding farms for the breeding of the Ukrainian red and white dairy breed («Kolos», Vinnitsa, "Yerchiki" of Zhytomyr, "Agroecology" of Poltava, State Enterprise "Gontarivka" of Kharkiv, "Bogdanivske, "Vidrodjennia" Cherkassy and " KrokUkrZalizBud" of Chernihiv regions).

The breeding and economic values of bulls was determined by the level of their initial breeding value, obtained for 305 days of the first lactation of the milk productivity of theirs daughters.

The calculation of the economic efficiency of using bulls with different breeding value, was carried out by calculating the value of produced additional milk by their cows - daughters by the formula [5]:

$$
\mathrm{E}=Ц \times \frac{\mathrm{P} \times \mathrm{H}}{100} \times Л \times K
$$

де: Ц - purchase price of one unit of milk, UAH;

$\mathrm{P}$ - milkproductivity of cows-comporaries for 305 days of lactation;

$\mathrm{H}$ - relative increase of daughters milkproductivity, \%;

$Л-$ coefficient $(0,75)$;

$\mathrm{K}$ - number of cows - daughters of each bull. 
Calculation of the purchase price of milk was carried out in accordance with sectoral recommendations of Ukraine 46.016 - 2002 [6]. The calculations were carried out using the method of mathematical statistics with the software package STATISTICA-6.1 [7].

Research results. The genealogy group of the bulls Leader 1926780 in .the Ukrainian red and white dairy breed, as of 01.01.2019, is represented by 13 improver bulls by the economic complex of useful traits of the Holstein breed of foreign selection and 8 bulls of domestic selection (fig.). Two bulls from which are estimated for offspring's quality and recognized as improvers of the complex of traits and 6 heads - estimated by pedigree and over 2500 cows.

The bulls belong to breeding enterprises: «Genetic Resources» - 5; «Ukrainian genetic company» - 4; research unity "Progress" - 2; «Main breeding center» - 2; Prat "Uman` breeding enterprise" - 2; «Poltavaplemservis» - 3 heads. Other companies have been delivered semen from the six bulls- improvers of this group from the United States and Germany.

A related group of Leader 1926780 bulls comes from the high-milking bloodline Cavaler 1620273 , whose animals are breeded in a number of European countries. In order to increase the content of fat and protein in milk, during the formation of the Leader group 1926780, great importance have been attached to selection of mothers of future cows for a number of traits (fat and protein content in milk, constancy of lactation curve, type of body structure, and duration of economic use). The bulls are very carefully selected in the countries of Europe (Germany, the Netherlands, Belgium), in which the minimum indicators of the quality of milk of cow-mothers of bulls were determined: the content of fat $-4.2 \%$, and protein $-3.4 \%$. For the inheritance of high yield of milk, the homozygosity of these traits in the offsprings was increased by applying different degrees of inbreeding to the ancestor of the bloodline. Between the 22 bulls of this group, represented in Ukraine, 10 bulls of them were obtained as a result of inbreeding (fig). Under these conditions, more than $70 \%$ their grandchildren inherited moderate quantitative and high quality (fat and protein content) of milk productivity traits.

At the present stage of selection with Ukrainian red and white dairy breed, one of the main tasks is the consolidation of animals by qualitative traits of milk productivity, the type of body structure and the preservation of high durability of economic use.

In order to ensure the consolidation of Ukrainian red and white dairy breed in a set of traits, 13 proven bulls-improvers of the related Leader group 1926780 have been brought to Ukraine, which are used in 27 breeding enterprises of Ukrainian red and white dairy breed. Among them: breed farms State Enterprise «Oleksandrivske» and «Kolos», of Vinnitsa, "Yerchiki" of Zhytomyr, "Agroecology" of Poltava, State Enterprise "Gontarivka", "Agrosvit", Kharkiv, State Enterprise "Khrystynivske", "Bogdanivske", and "Vidrodzhennya", of Cherkassy, "KrokUkrZalizBud" of Chernigov regions.

The analysis of the breeding value of the bulls of the related Leader 1926780 group, which are used in breeding farms for the breeding of the Ukrainian red and white dairy breed (table 1) indicates, that the animals of thise related group of European origin well combine moderately high tastes with a fairly high fat content and protein in milk, have a good type of body structure and technological properties of udder and well transfer these traits by inheritance.

The initial breeding value for the daughter's milk productivity of bulls of foreign selection was $+400-+1406$ and domestic -+748 and $+1261 \mathrm{~kg}$. Along with a high level of breeding value the bulls of this related group are characterized by high contents of fat and protein in milk. Thus, the fat content in milk of the daughters of bulls (10 heads), which ware estimated in Germany, was at the level of $4.16-4.55 \%$ and protein content $-3.28-3.53 \%$. The pedigree value of bulls by these traits ware +0.10 -+0.59 and $+0.02-+0.35 \%$ and exceeds the standards of Ukrainian red and white dairy breed by 12.5-30.0 and 9.1\% respectively. Typical, that the bulls of domestic breeding inherit high fat content in milk (breeding value is $+0.02-+0.18 \%)$ and protein $(+0.02-+0.15 \%)$. During a long-term using, the breeding value of all bulls is decreasing annually due to increasing the level of genetic trend of milk productivity in herds, remains at a positive level and provides improvement of the animals of the breeding herds in which they are used, according to the complex of breeding traits. 
As a result of the research it was found, that the milk productivity of the daughters of the young bulls of this genealogy group such as Kurgan DE 113836267, Kompass DE 113996021 and Golf DE 114468012, which have been first time evaluated for the offspring quality, was higher in the herd of the breeding plant of «Krok-UkrZalizBud" than at the compararies-daughters of the well-known bulls of the time (Varnak 9537, Col 7400040229, Turino 660563141, Roller 220593945, Campino 112825601, Faggio 532148106) for 305 days of the first lactation at $+207-+697 \mathrm{~kg}$. At the same time, the fat and protein content in milk was higher on $+0.01-+0.09 \%$. (table 2 ). During the second lactation, the daughters of these bulls also keeped their first places of yield of milk, fat and protein content. At higher lactation, they, with a slight increase in yield of milk, exceeded their peers for qualitative characteristics of milk production, with a fat content of $+0.04-+0.06$ and protein $-+0.04-0.07 \%$. At present, the bull Golf is used in the herds of the State Enterprise "Gontarivka" and "Agrosvit" breeding plant in the Kharkiv region, in which a high level of cows feeding, breeding young animals and assessing the quality of milk are provided. The milk productivity of the 15 firstborn cows for 305 days of lactation in the state enterprise "Gontarivka" constituted $6113 \mathrm{~kg}$ whis $4.03 \%$ fat and $3.33 \%$ protein, while in the "Agrosvit" breeding plant from each of 41 first-born Golf"s cows was obtained at $6893 \mathrm{~kg}$ of milk with $4.01 \%$ fat content and $3.38 \%$ protein. The breeding value of this bull is $+526 \mathrm{~kg}$ milk, $+0.31 \%$ fat and $+0.28 \%$ protein, which prevails breed standard for milk yield by $91-115$; fat content $8.3-9.0$; and protein by $0.1-2.4 \%$ respectively.

The distribution of the Kanzler DE 768305280 daughters, in the breeding factory of the «Yerchyky» of Zhytomyr region, for the content of fat in milk was following: at the level of standard and below the standard of breed (3.7\% and less) was 37.2 and above the standard - $(3.8 \%$ and above) $-62.8 \%$. and by content protein $(2.5-3.3 \%)-28.6$ and $(3.4-4.3 \%)-71.4 \%$.

The bull Konbeo Red DE 579810507 was used simultaneously with the Jornado Red DE 114386106 , whose breeding value was $+1100 \mathrm{~kg}+0.02 \%+42 \mathrm{~kg}+0.0+33 \mathrm{~kg}$ at the farm «Kolos» breeding plant in the Vinnitsa region. The milk productivity of the Konbeo daughters during the first two lactations exceeded the compararies at $334-392 \mathrm{~kg}$ of milk, the fat content $+0.03-+0.04$ and the protein at $+0.02-0.04 \%$. During the third lactation, the yield of milk of the cows of both groups was almost equal, however, the fat content of milk in the cows of the Konbeo continued to exceed on $0.04 \%$.

Among the bulls of domestic breeding should be noted Agrus Red UA 320080992043, was born in 2006 (the Main Breeding Center), estimated in $2015 \mathrm{SI}+706$ (94 dt. $-8739 \mathrm{~kg}-3.96 \%$ fat $347 \mathrm{~kg}$ of milk fat; $3.17 \%$ protein and $277 \mathrm{~kg}$ of protein). The breeding value was: $+744 \mathrm{~kg}-+0.18 \%$ $+44 \mathrm{~kg}+0.02 \%$ and $+18 \mathrm{~kg}$. The yield of milk of his daughter Rosalia UA 7100625433, for 305 days of the fourth lactation was $11847 \mathrm{~kg}$ with $4.01 \%$ content and $475 \mathrm{~kg}$ of milk fat and $3.29 \%(390 \mathrm{~kg})$ of protein. Another cow - Ptytsia UA 7100514533 for 305 days of the fourth lactation produced 8555 $\mathrm{kg}$ milk at $3.93 \%(336 \mathrm{~kg})$ of milk fat and $3.28 \%(281 \mathrm{~kg})$ of protein.

In the genealogical structure of the related group of Leader 1926780, three separate branches were created through the bulls of Goldgi 706570603, K. Leader 775157228 and Flanno 2153299. As a result of the successful combination of the daughters of the domestic selection of bull Agrus Red UA 3200801693 (branch of the Flano) of the Ukrainian red and white dairy breed with bull Golf 114468012 (branch of Goldgi) in the breeding plant "Vidrodzhennia" of Cherkassy region, using a remote degree of inbreeding (IV-V), a group of high-yielding of milk cows was received which, according to the type of body structure and milk productivity response to desirable typ of cows of the Ukrainian red and white dairy breed. Among them cow Golubka UA 4600487021, (H 93.7\% + S $6.3 \%$ ) yield of milk for 305 days of the second lactation was $10750 \mathrm{~kg}$ with a fat content in milk of 3.85 and a protein of $3.31 \%$. From bull Kollo 77789825 a model for the central type of Ukrainian red and white dairy breed the cow Malvina was obtained ("Krok-UkrZalizBud"). This cow, during 305 days of the second lactation, produced $10263 \mathrm{~kg}$ of milk with content $3.96 \%$ fat and $3.15 \%$ protein. 


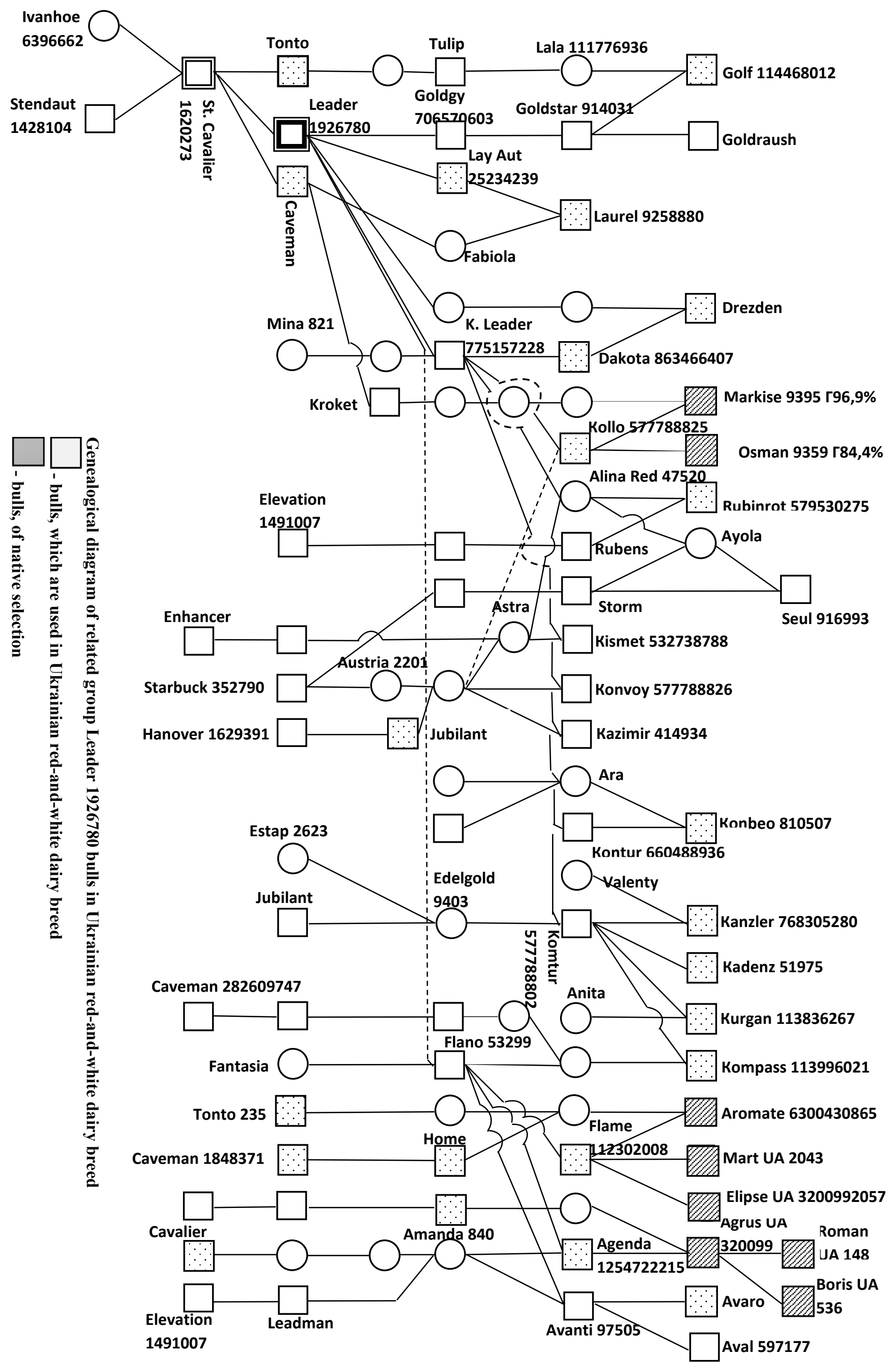


1. The dinamics of the breeding value of the related Leader's group bulls 1926780

\begin{tabular}{|c|c|c|c|c|c|c|c|}
\hline \multirow[b]{2}{*}{$\begin{array}{l}\text { Name, number, birth- } \\
\text { day and place of birth }\end{array}$} & \multirow{2}{*}{$\begin{array}{l}\text { Method, year } \\
\text { of value, num- } \\
\text { ber of daugh- } \\
\text { ters, } \mathrm{R}\end{array}$} & \multirow[b]{2}{*}{$\begin{array}{l}\text { Selection } \\
\text { index }\end{array}$} & \multicolumn{5}{|c|}{ Milkproductivity, breeding value } \\
\hline & & & $\begin{array}{l}\text { yield of } \\
\text { milk, kg }\end{array}$ & $\begin{array}{l}\text { content } \\
\text { of fat, } \\
\%\end{array}$ & fat, $\mathrm{kg}$ & $\begin{array}{l}\text { content } \\
\text { of pro- } \\
\text { tein, } \%\end{array}$ & protein, $\mathrm{kg}$ \\
\hline 1 & 2 & 3 & 4 & 5 & 6 & 7 & 8 \\
\hline \multicolumn{8}{|c|}{ The bulls of foreign selection } \\
\hline \multirow{3}{*}{$\begin{array}{l}\text { Rubinrot DE } \\
579530275,2002 \\
\text { H } 100 \%\end{array}$} & $\begin{array}{c}\text { ZW'09 93\%* }^{\prime}{ }^{\prime} \text { 117 dt. }\end{array}$ & +1618 & $\begin{array}{r}7277 \\
+498\end{array}$ & $\begin{array}{c}4.41 \\
+0.59\end{array}$ & $\begin{array}{l}321 \\
+62\end{array}$ & $\begin{array}{c}3.53 \\
+0.35\end{array}$ & $\begin{array}{l}257 \\
+41\end{array}$ \\
\hline & $\begin{array}{c}\text { ZW`1196\% } \\
475 \mathrm{dt} .\end{array}$ & +1776 & $\begin{array}{l}8408 \\
+500\end{array}$ & $\begin{array}{l}4.53 \\
+0.59\end{array}$ & $\begin{array}{l}381 \\
+69\end{array}$ & $\begin{array}{c}3.66 \\
+0.35\end{array}$ & $\begin{array}{l}308 \\
+46\end{array}$ \\
\hline & $\begin{array}{l}\text { ZW'15 } \\
1068 \mathrm{dt} .\end{array}$ & +785 & +14 & +0.61 & +48 & +0.33 & +26 \\
\hline \multirow{6}{*}{$\begin{array}{l}\text { Kanzler DE } \\
768305280 \\
2003 \\
\text { H } 100 \%\end{array}$} & $\begin{array}{c}\text { ZW'09 92\% } \text { (1) } \\
90 \mathrm{dt} .\end{array}$ & +1702 & $\begin{array}{l}6926 \\
+667\end{array}$ & $\begin{array}{c}4.46 \\
+0.40\end{array}$ & $\begin{array}{l}309 \\
+55\end{array}$ & $\begin{array}{c}3.47 \\
+0.06\end{array}$ & $\begin{array}{l}240 \\
+28\end{array}$ \\
\hline & $\begin{array}{c}\text { ZW'1195\% } \\
\text { 95dt. }\end{array}$ & +2035 & $\begin{array}{l}8129 \\
+877\end{array}$ & $\begin{array}{c}4.61 \\
+0.40\end{array}$ & $\begin{array}{l}375 \\
+70\end{array}$ & $\begin{array}{c}3051 \\
+0.06\end{array}$ & $\begin{array}{l}285 \\
+35\end{array}$ \\
\hline & $\begin{array}{l}Z^{\prime} 13 \\
723 \mathrm{dt} .\end{array}$ & +1898 & $\begin{array}{r}8129 \\
+581\end{array}$ & $\begin{array}{c}4.61 \\
+0.50\end{array}$ & $\begin{array}{l}375 \\
+65\end{array}$ & $\begin{array}{c}3.51 \\
+0.12\end{array}$ & $\begin{array}{r}285 \\
+29\end{array}$ \\
\hline & $\begin{array}{c}W^{\prime} 1599 \% \\
1031 \mathrm{dt} .\end{array}$ & +1322 & $\begin{array}{l}8826 \\
+565\end{array}$ & $\begin{array}{c}4.55 \\
+0.49\end{array}$ & $\begin{array}{l}401 \\
+65\end{array}$ & $\begin{array}{c}3.47 \\
+0.10\end{array}$ & $\begin{array}{l}306 \\
+28\end{array}$ \\
\hline & $\begin{array}{l}\text { CBV'16** }^{*} 16^{\prime} \\
1001 \mathrm{dt} .\end{array}$ & +487 & $\begin{array}{r}7523 \\
+206\end{array}$ & $\begin{array}{c}3.77 \\
+0.02\end{array}$ & $\begin{array}{c}284 \\
+8\end{array}$ & $\begin{array}{c}3.19 \\
+0\end{array}$ & $\begin{array}{c}240 \\
+6\end{array}$ \\
\hline & $\begin{array}{c}\text { CBV'}^{\prime} 17 \\
1383 \text { dt. } 99 \% \\
\end{array}$ & +348 & $\begin{array}{r}7518 \\
+202 \\
\end{array}$ & $\begin{array}{c}3.74 \\
+0.02 \\
\end{array}$ & $\begin{array}{r}282 \\
+10 \\
\end{array}$ & $\begin{array}{c}3.18 \\
+0.01 \\
\end{array}$ & $\begin{array}{c}239 \\
+6 \\
\end{array}$ \\
\hline \multirow{3}{*}{$\begin{array}{l}\text { Kollo DE } \\
5777898825 \\
1997 \\
\text { H } 100 \%\end{array}$} & $\begin{array}{c}\mathrm{ZW}^{\prime} 04 \\
71 \mathrm{dt} .89 \% \\
\end{array}$ & +1997 & $\begin{array}{r}8811 \\
+1285 \\
\end{array}$ & $\begin{array}{c}4.20 \\
+0.34 \\
\end{array}$ & $\begin{array}{r}370 \\
+57 \\
\end{array}$ & $\begin{array}{c}3.60 \\
+0.23 \\
\end{array}$ & $\begin{array}{r}317 \\
+61 \\
\end{array}$ \\
\hline & $\begin{array}{c}\text { CBV }^{\prime} 13 \\
129 \text { dt. } 88 \%\end{array}$ & +1614 & $\begin{array}{c}8116 \\
+1812\end{array}$ & $\begin{array}{r}3.79 \\
-0.02\end{array}$ & $\begin{array}{l}307 \\
+68\end{array}$ & $\begin{array}{c}3.08 \\
+0.04\end{array}$ & $\begin{array}{l}250 \\
+58\end{array}$ \\
\hline & $\begin{array}{c}\text { ZW'15 } \\
3203 \text { dt. } 99 \% \\
\end{array}$ & +1183 & +155 & +0.14 & +17 & +0.25 & +25 \\
\hline \multirow{3}{*}{$\begin{array}{l}\text { Flame DE } \\
112302008 \\
1999 \\
\text { H } 100 \%\end{array}$} & $\begin{array}{c}\text { ZW'04 } \\
65 \text { dt. } 76 \%\end{array}$ & +766 & $\begin{array}{l}8107 \\
+400\end{array}$ & $\begin{array}{l}4.55 \\
+0.36\end{array}$ & $\begin{array}{l}369 \\
+46\end{array}$ & $\begin{array}{c}3.52 \\
-0.07\end{array}$ & $\begin{array}{l}285 \\
+18\end{array}$ \\
\hline & CBV'14 & +560 & $\begin{array}{l}7331 \\
+150\end{array}$ & $\begin{array}{c}3.87 \\
+0.02\end{array}$ & $\begin{array}{c}283 \\
+6\end{array}$ & $\begin{array}{c}3.27 \\
+0.01\end{array}$ & $\begin{array}{c}240 \\
+5\end{array}$ \\
\hline & $\begin{array}{l}\text { CBV'16 }^{\prime} 162 \mathrm{dt} .\end{array}$ & +278 & $\begin{array}{r}7477 \\
+340\end{array}$ & $\begin{array}{c}3.87 \\
+0.02\end{array}$ & $\begin{array}{r}289 \\
+14\end{array}$ & $\begin{array}{c}3.25 \\
0\end{array}$ & $\begin{array}{l}243 \\
+11\end{array}$ \\
\hline \multirow{5}{*}{$\begin{array}{l}\text { Konbeo Red DE } \\
579810507 \\
2003 \\
\text { H } 100 \%\end{array}$} & $\begin{array}{c}\text { ZW'09 } \\
98 \text { dt. } 90 \%\end{array}$ & +1250 & $\begin{array}{r}7683 \\
+829\end{array}$ & $\begin{array}{c}4.17 \\
+0.38\end{array}$ & $\begin{array}{l}320 \\
+60\end{array}$ & $\begin{array}{c}3.42 \\
+0.06\end{array}$ & $\begin{array}{l}263 \\
+33\end{array}$ \\
\hline & $\begin{array}{c}\text { ZW'13 }^{\prime} 13 \\
114 \text { dt. } 93 \%\end{array}$ & +356 & +203 & +0.29 & +32 & +0.04 & +11 \\
\hline & $\begin{array}{l}Z_{\text {ZW'16 }} 16 \\
258 \mathrm{dt} .\end{array}$ & +341 & $\begin{array}{l}8932 \\
+362\end{array}$ & $\begin{array}{c}3.87 \\
+0.02\end{array}$ & $\begin{array}{l}346 \\
+24\end{array}$ & $\begin{array}{c}3.20 \\
+0.23\end{array}$ & $\begin{array}{l}286 \\
+12\end{array}$ \\
\hline & $\begin{array}{c}\mathrm{ZW}^{\prime} 17 \\
300 \mathrm{dt} .96 \%\end{array}$ & +557 & $\begin{array}{r}9003 \\
+592 \\
\end{array}$ & $\begin{array}{c}3.88 \\
+0.02 \\
\end{array}$ & $\begin{array}{l}350 \\
+26\end{array}$ & $\begin{array}{c}3.19 \\
+0.01\end{array}$ & $\begin{array}{l}287 \\
+19 \\
\end{array}$ \\
\hline & $\begin{array}{c}Z^{2} W^{\prime} 18 \\
363 \text { dt. } 98 \% \\
\end{array}$ & +382 & $\begin{array}{r}9080 \\
+726 \\
\end{array}$ & $\begin{array}{c}3.88 \\
+0.02 \\
\end{array}$ & $\begin{array}{r}350 \\
+30 \\
\end{array}$ & $\begin{array}{c}3.18 \\
+0.00 \\
\end{array}$ & $\begin{array}{r}260 \\
+28 \\
\end{array}$ \\
\hline \multirow{2}{*}{$\begin{array}{l}\text { Laurel DE } 925880 \\
1999 \\
\text { H } 100 \%\end{array}$} & $\begin{array}{c}\mathrm{WW}^{\prime} 05 \\
71 \mathrm{dt} .80 \%\end{array}$ & & $\begin{array}{r}7695 \\
+741 \\
\end{array}$ & $\begin{array}{c}4.16 \\
+0.02 \\
\end{array}$ & $\begin{array}{l}320 \\
+33 \\
\end{array}$ & $\begin{array}{c}3.38 \\
+0.04 \\
\end{array}$ & $\begin{array}{r}283 \\
+28 \\
\end{array}$ \\
\hline & $\begin{array}{c}\text { ZW'09 } \\
128 \text { dt. } 91 \%\end{array}$ & & $\begin{array}{l}9123 \\
+146 \\
\end{array}$ & $\begin{array}{c}4.22 \\
+0.22 \\
\end{array}$ & $\begin{array}{r}383 \\
+23 \\
\end{array}$ & $\begin{array}{c}3.48 \\
+0.13 \\
\end{array}$ & $\begin{array}{r}317 \\
+15 \\
\end{array}$ \\
\hline \multirow{2}{*}{$\begin{array}{l}\text { Agende Et Red US } \\
124722215 \\
1998 \\
\text { H } 100 \%\end{array}$} & $\begin{array}{c}\text { PTA'03 } \\
63 \text { dt. } 78 \%\end{array}$ & +881 & $\begin{array}{l}10405 \\
+1071\end{array}$ & $\begin{array}{c}3.77 \\
+0.10\end{array}$ & $\begin{array}{l}388 \\
+50\end{array}$ & $\begin{array}{c}3.28 \\
-0.02\end{array}$ & $\begin{array}{l}341 \\
+33\end{array}$ \\
\hline & $\begin{array}{c}\text { CBV'13 }^{\prime} 13 \\
47 \mathrm{dt} .78 \%\end{array}$ & +857 & $\begin{array}{c}7034 \\
+1084\end{array}$ & $\begin{array}{c}3.68 \\
+0.02\end{array}$ & $\begin{array}{l}258 \\
+40\end{array}$ & $\begin{array}{c}3.04 \\
-0.10\end{array}$ & $\begin{array}{l}213 \\
+27\end{array}$ \\
\hline \multirow{2}{*}{$\begin{array}{l}\text { Avaro Red DE } \\
580607151 \\
2005 \\
\text { H } 100 \%\end{array}$} & $\begin{array}{c}\text { ZW'11 }^{\prime} \\
90 \%\end{array}$ & +1560 & $\begin{array}{c}7932 \\
+1270\end{array}$ & $\begin{array}{c}3.98 \\
-0.25\end{array}$ & $\begin{array}{l}316 \\
+31\end{array}$ & $\begin{array}{c}3.37 \\
+0.02\end{array}$ & $\begin{array}{r}268 \\
+45\end{array}$ \\
\hline & $\begin{array}{c}Z^{\prime} W^{\prime} 15 \\
91 \mathrm{dt} .80 \%\end{array}$ & +1142 & +1157 & -0.27 & +24 & +0.01 & +40 \\
\hline
\end{tabular}


continuation of tab. 1

\begin{tabular}{|c|c|c|c|c|c|c|c|}
\hline 1 & 2 & 3 & 4 & 5 & 6 & 7 & 8 \\
\hline \multirow{3}{*}{$\begin{array}{l}\text { Kadenz DE } \\
114151975 \\
2003 \\
\text { H } 100 \%\end{array}$} & ZW'09 & \multirow[t]{2}{*}{+1598} & 7700 & 4.22 & 325 & 3.39 & 261 \\
\hline & 86 dt. $92 \%$ & & & & +57 & -0.01 & +47 \\
\hline & $\begin{array}{c}\text { CBV }^{\prime} 15 \\
441 \text { dt } 99 \%\end{array}$ & +886 & $\begin{array}{l}8008 \\
+662\end{array}$ & $\begin{array}{c}3.84 \\
+0\end{array}$ & $\begin{array}{l}308 \\
+28\end{array}$ & $\begin{array}{c}3.22 \\
+0\end{array}$ & $\begin{array}{l}258 \\
+21\end{array}$ \\
\hline \multirow{5}{*}{$\begin{array}{l}\text { Kompass DE } \\
57788802 \\
2003 \\
\text { H } 100 \%\end{array}$} & CBV'13 & \multirow{2}{*}{+475} & 5122 & 3.96 & 203 & 3.06 & 157 \\
\hline & 122 dt. $82 \%$ & & +498 & +0.40 & +38 & +0.12 & +21 \\
\hline & CBV'15 & \multirow{2}{*}{+497} & 6728 & 3.90 & 262 & 3.18 & 214 \\
\hline & 348 dt. $95 \%$ & & +332 & +0.16 & +22 & +0.08 & +16 \\
\hline & $\begin{array}{c}\text { CBV }^{\prime} 17 \\
443 \text { dt. } 96 \%\end{array}$ & +655 & $\begin{array}{r}6935 \\
+576\end{array}$ & $\begin{array}{c}3.90 \\
+0.14\end{array}$ & $\begin{array}{l}270 \\
+30\end{array}$ & $\begin{array}{c}3.16 \\
+0.06\end{array}$ & $\begin{array}{l}219 \\
+22\end{array}$ \\
\hline \multirow{5}{*}{$\begin{array}{l}\text { Kurgan Red DE } \\
113836267 \\
2003 \\
\text { H } 100 \%\end{array}$} & $\mathrm{CBV}^{\prime} 13$ & \multirow{2}{*}{+612} & 7747 & 3.70 & 286 & 3.08 & 238 \\
\hline & 40 dt. $71 \%$ & & +578 & -0.06 & +20 & -0.02 & +17 \\
\hline & CBV'14 & \multirow{2}{*}{+590} & 8005 & 3.64 & 290 & 3.08 & 247 \\
\hline & 52 dt. $78 \%$ & & +684 & -0.08 & +20 & +0.00 & +22 \\
\hline & $\begin{array}{c}\text { CBV'15 } \\
204 \text { dt. } 93 \%\end{array}$ & +1478 & $\begin{array}{r}8274 \\
+1478 \\
\end{array}$ & $\begin{array}{r}3.86 \\
+0.04 \\
\end{array}$ & $\begin{array}{r}319 \\
+60 \\
\end{array}$ & $\begin{array}{r}3.21 \\
+0.02 \\
\end{array}$ & $\begin{array}{r}266 \\
+49 \\
\end{array}$ \\
\hline \multirow{5}{*}{$\begin{array}{l}\text { Golf DE } 114468012 \\
2003 \\
\text { H } 100 \%\end{array}$} & CBV'15 & \multirow{2}{*}{+259} & 6416 & 3.72 & 238 & 3.05 & 196 \\
\hline & 326 dt. $96 \%$ & & +296 & +0.02 & +12 & +0.00 & +9 \\
\hline & $\begin{array}{c}\text { CBV'16 } \\
552 \text { dt. } 98 \%\end{array}$ & +475 & $\begin{array}{l}6891 \\
+548\end{array}$ & $\begin{array}{c}3.73 \\
+0.02\end{array}$ & $\begin{array}{l}257 \\
+20\end{array}$ & $\begin{array}{c}3.10 \\
+0.00\end{array}$ & $\begin{array}{l}214 \\
+17\end{array}$ \\
\hline & CBV'18 & \multirow{2}{*}{+475} & 6908 & 3.74 & 258 & 3.10 & 214 \\
\hline & $577 \mathrm{dt}$. & & +522 & +0.02 & +20 & +0.00 & +16 \\
\hline \multirow{2}{*}{$\begin{array}{l}\text { Drezden Red DE } \\
10595084 \\
1999 \\
\text { H } 87,5 \%+ \\
\text { HO } 12,5 \%\end{array}$} & $\mathrm{ZW}^{\prime} 04$ & +1037 & $\begin{array}{c}6916 \\
+1146\end{array}$ & $\begin{array}{c}3.88 \\
-0.33\end{array}$ & $\begin{array}{l}268 \\
-25\end{array}$ & $\begin{array}{l}3.35 \\
+0.01\end{array}$ & $\begin{array}{l}232 \\
+40\end{array}$ \\
\hline & $\begin{array}{c}\text { CBV'13 } \\
55 \mathrm{dt} .77 \%\end{array}$ & +475 & $\begin{array}{l}6551 \\
+632\end{array}$ & $\begin{array}{c}3.83 \\
-0.08\end{array}$ & $\begin{array}{l}251 \\
+20\end{array}$ & $\begin{array}{r}2.98 \\
-0.02\end{array}$ & $\begin{array}{l}195 \\
+17\end{array}$ \\
\hline \multicolumn{8}{|c|}{ The bulls of native selection } \\
\hline \multirow{2}{*}{$\begin{array}{l}\text { Agrus Red } \\
\text { UA32000801693, } \\
2006, \text { H } 100 \%\end{array}$} & $\begin{array}{l}\text { CBV'14 } \\
80 \mathrm{dt} .\end{array}$ & +612 & $\begin{array}{l}8726 \\
+748\end{array}$ & $\begin{array}{c}4.00 \\
+0.18\end{array}$ & $\begin{array}{l}349 \\
+46\end{array}$ & $\begin{array}{c}3.17 \\
+0.02\end{array}$ & $\begin{array}{l}276 \\
+18\end{array}$ \\
\hline & $\begin{array}{c}\text { CBV'15 } \\
94 \text { dt. } 84 \%\end{array}$ & +706 & $\begin{array}{r}8739 \\
+744\end{array}$ & $\begin{array}{r}3.96 \\
+0.18\end{array}$ & $\begin{array}{l}347 \\
+44\end{array}$ & $\begin{array}{c}3.17 \\
+0.02\end{array}$ & $\begin{array}{r}297 \\
+18\end{array}$ \\
\hline $\begin{array}{l}\text { Markise UA } \\
5300159395,2005 \\
\text { H 96,9\%+ S3,1\% }\end{array}$ & $\begin{array}{c}\text { CBV'15 }^{\prime} 15 \\
129 \text { dt. } 87 \%\end{array}$ & +1450 & $\begin{array}{c}8690 \\
+1261\end{array}$ & $\begin{array}{c}3.74 \\
+0.02\end{array}$ & $\begin{array}{l}325 \\
+52\end{array}$ & $\begin{array}{c}3.28 \\
+0.15\end{array}$ & $\begin{array}{l}285 \\
+51\end{array}$ \\
\hline $\begin{array}{l}\text { Osman UA } \\
5300159359,2005 \\
\text { H 84,4\%+S 15,6\% }\end{array}$ & CBV'13 & $\begin{array}{c}\mathrm{PI} \\
+1022 * * *\end{array}$ & $\begin{array}{c}6685 \\
+1052\end{array}$ & $\begin{array}{c}3.78 \\
+0.02\end{array}$ & $\begin{array}{l}252 \\
+45\end{array}$ & $\begin{array}{c}3.26 \\
+0.14\end{array}$ & $\begin{array}{l}217 \\
+44\end{array}$ \\
\hline \multirow{2}{*}{$\begin{array}{l}\text { Mart UA } \\
3200992043,2009 \\
\text { H 93,9\%+ S 6,1\% }\end{array}$} & CBV'14 & $\mathrm{PI}+1028$ & $\begin{array}{c}9985 \\
+1326\end{array}$ & $\begin{array}{c}3.98 \\
+0.01\end{array}$ & $\begin{array}{l}397 \\
+49\end{array}$ & $\begin{array}{c}3.16 \\
+0.01\end{array}$ & $\begin{array}{l}316 \\
+45\end{array}$ \\
\hline & CBV'16 & +1142 & +1421 & +0.01 & +53 & 0.01 & +48 \\
\hline \multirow{2}{*}{$\begin{array}{l}\text { Elipse UA } \\
3200992157,2009 \\
\text { H } 100 \%\end{array}$} & CBV'09 & $\mathrm{PI}+1344$ & $\begin{array}{c}8244 \\
+1302 \\
\end{array}$ & $\begin{array}{r}3.96 \\
+0.22 \\
\end{array}$ & $\begin{array}{l}326 \\
+69 \\
\end{array}$ & $\begin{array}{c}3.17 \\
+0.04 \\
\end{array}$ & $\begin{array}{l}261 \\
+48 \\
\end{array}$ \\
\hline & CBV'16 & $\mathrm{PI}+1160$ & +1535 & +0 & +58 & +0.01 & +49 \\
\hline $\begin{array}{l}\text { Aromat UA } \\
6300430865,2008 \\
\text { H 93,8\%+ S 6,2\% } \\
\end{array}$ & CBV'08 & $\mathrm{PI}+870$ & $\begin{array}{l}6385 \\
+929\end{array}$ & $\begin{array}{l}4.06 \\
+0.24\end{array}$ & $\begin{array}{l}259 \\
+57\end{array}$ & $\begin{array}{c}3.19 \\
+0.06\end{array}$ & $\begin{array}{l}204 \\
+34\end{array}$ \\
\hline $\begin{array}{l}\text { Boris UA } \\
7100514536,2009 \\
\text { H } 100\end{array}$ & CBV'15 & $\mathrm{PI}+646$ & 520 & +0.13 & +30 & +0.01 & +12 \\
\hline $\begin{array}{l}\text { Roman Red UA } \\
7100600148,2009 \\
\text { H 93,8\% + S 6,2\% } \\
\end{array}$ & CBV'15 & $\mathrm{PI}+552$ & +713 & +0.11 & +37 & +0.01 & +18 \\
\hline
\end{tabular}

*ZW - zuchtwert (Germany); **CBV - calculation breeding value (Ukraine); *** PI - pedigree index 
2. The daughter's milkproductivity of the related Leader 1926780 group bulls a.The bull Kurgan DE 113836267, breeding farm «Krok-UkrZalizBud»

\begin{tabular}{|l|c|c|c|c|}
\hline \multicolumn{1}{|c|}{ Characteristic } & $\begin{array}{c}\text { High lactation } \\
(305 \text { days })\end{array}$ & $\begin{array}{c}\text { First lactation } \\
(\mathrm{n}=137)\end{array}$ & $\begin{array}{c}\text { Second lactation } \\
(\mathrm{n}=94)\end{array}$ & $\begin{array}{c}\text { Third lactation } \\
(\mathrm{n}=60)\end{array}$ \\
\hline Yield of milk, kg & $6962 \pm 174$ & $5873 \pm 144$ & $7346 \pm 214$ & $7627 \pm 274$ \\
\hline Cv, $\%$ & 29,2 & 28,7 & 28,2 & 27,9 \\
\hline Fat content, \% & $3.96 \pm 0.009$ & $3.98 \pm 0.009$ & $3.81 \pm 0.007$ & $3.87 \pm 0.01$ \\
\hline Cv, \% & 2.5 & 2.5 & 1.8 & 2.3 \\
\hline Fat, kg & $276 \pm 6.9$ & $234 \pm 5.9$ & $280 \pm 8.3$ & $289 \pm 9.5$ \\
\hline Cv, \% & 29.3 & 29.5 & 35.0 & 25.6 \\
\hline Protein content, \% & $3.28 \pm 0.009$ & $3.24 \pm 0.009$ & $3.19 \pm 0.006$ & $3.28 \pm 0.01$ \\
\hline Cv, \% & 3.1 & 3.1 & 2.6 & 3.0 \\
\hline Protein, kg & $229 \pm 5.9$ & $191 \pm 5.0$ & $235 \pm 8.6$ & $245 \pm 8.0$ \\
\hline Cv, \% & 30.1 & 30.4 & 35.3 & 25.7 \\
\hline
\end{tabular}

b. The bull Kompass DE 113996021 breeding farm «Krok-UkrZalizBud»"

\begin{tabular}{|l|c|c|c|c|}
\hline \multicolumn{1}{|c|}{ Characteristic } & $\begin{array}{c}\text { High lactation } \\
\text { (305 days) }\end{array}$ & $\begin{array}{c}\text { First lactation } \\
(\mathrm{n}=88)\end{array}$ & $\begin{array}{c}\text { Second lactation } \\
(\mathrm{n}=16)\end{array}$ & $\begin{array}{c}\text { Third lactation } \\
(\mathrm{n}=4)\end{array}$ \\
\hline Yield of milk, $\mathrm{kg}$ & $6597 \pm 207$ & $5609 \pm 145$ & $6353 \pm 296$ & $6501 \pm 469$ \\
\hline $\mathrm{Cv}, \%$ & 29.4 & 24.0 & 33.3 & 38.2 \\
\hline Fat content, \% & $3.94 \pm 0.01$ & $3.92 \pm 0.01$ & $3.94 \pm 0.01$ & $3.92 \pm 0.006$ \\
\hline $\mathrm{Cv}, \%$ & 2.3 & 2.3 & 2.5 & 0.7 \\
\hline Fat, $\mathrm{kg}$ & $261 \pm 8.3$ & $220 \pm 5.8$ & $251 \pm 12.0$ & $256 \pm 18.7$ \\
\hline $\mathrm{Cv}, \%$ & 29.9 & 24.5 & 34.3 .0 & 38.7 \\
\hline Protein content, \% & $3.17 \pm 0.01$ & $3.09 \pm 0.006$ & $3.18 \pm 0.02$ & $3.23 \pm 0.006$ \\
\hline $\mathrm{Cv}, \%$ & 3.8 & 1.9 & 3.8 & 0.9 \\
\hline Protein, $\mathrm{kg}$ & $211 \pm 7.0$ & $174 \pm 4.5$ & $203 \pm 10.0$ & $211 \pm 15.7$ \\
\hline $\mathrm{Cv}, \%$ & 31.3 & 24 & 35.5 & 39.3 \\
\hline
\end{tabular}

c. The bull Golf DE 114468012, breeding farm «Krok- UkrZalizBud»

\begin{tabular}{|c|c|c|c|c|}
\hline Characteristic & $\begin{array}{l}\text { High lactation } \\
\text { (305 days) }\end{array}$ & $\begin{array}{l}\text { First lactation } \\
\quad(\mathrm{n}=111)\end{array}$ & $\begin{array}{l}\text { Second lactation } \\
\quad(\mathrm{n}=83)\end{array}$ & $\begin{array}{l}\text { Third lactation } \\
\quad(\mathrm{n}=42)\end{array}$ \\
\hline Yield of milk, kg & $6709 \pm 197$ & $5383 \pm 139$ & $6703 \pm 229$ & $6630 \pm 397$ \\
\hline $\mathrm{Cv}, \%$ & 30.8 & 27.0 & 31.1 & 38.8 \\
\hline Fat content, $\%$ & $3.95 \pm 0.009$ & $3.95 \pm 0.009$ & $3.93 \pm 0.01$ & $3.88 \pm 0.01$ \\
\hline $\mathrm{Cv}, \%$ & 2.3 & 2.3 & 2.3 & 2.3 \\
\hline Fat, kg & $265 \pm 7.9$ & $213 \pm 5.6$ & $264 \pm 9.3$ & $250 \pm 16.7$ \\
\hline $\mathrm{Cv}, \%$ & 31.3 & 27.7 & 32.2 & 43.2 \\
\hline Protein content, \% & $3.23 \pm 0.01$ & $3.18 \pm 0.01$ & $3.25 \pm 0.01$ & $3.18 \pm 0.08$ \\
\hline $\mathrm{Cv}, \%$ & 3.4 & 3.1 & 3.1 & 16.4 \\
\hline Protein, $\mathrm{kg}$ & $721 \pm 6.7$ & $171 \pm 4.5$ & $217 \pm 8.1$ & $212 \pm 14.2$ \\
\hline $\mathrm{Cv}, \%$ & 32.3 & 27.5 & 33.5 & 43.4 \\
\hline
\end{tabular}

d. Contemporaryes of the Kurgan, Golf and Kompass bulls

\begin{tabular}{|l|c|c|c|c|}
\hline \multicolumn{1}{|c|}{ Characteristic } & $\begin{array}{c}\text { High lactation } \\
\text { (305 days) }\end{array}$ & $\begin{array}{c}\text { First lactation } \\
(\mathrm{n}=47)\end{array}$ & $\begin{array}{c}\text { Second lactation } \\
(\mathrm{n}=36)\end{array}$ & $\begin{array}{c}\text { Third lactation } \\
(\mathrm{n}=24)\end{array}$ \\
\hline Yield of milk, $\mathrm{kg}$ & $6552 \pm 288$ & $5176 \pm 164$ & $5613 \pm 346$ & $6858 \pm 418$ \\
\hline $\mathrm{Cv}, \%$ & 30.2 & 21.8 & 36.9 & 29.8 \\
\hline Fat content, \% & $3.90 \pm 0.01$ & $3.94 \pm 0.01$ & $3.88 \pm 0.01$ & $3.94 \pm 0.02$ \\
\hline Cv, \% & 2.1 & 1.8 & 1.8 & 2.8 \\
\hline Fat, $\mathrm{kg}$ & $256 \pm 11.4$ & $204 \pm 6.6$ & $218 \pm 13.7$ & $271 \pm 17.3$ \\
\hline Cv, \% & 30.5 & 22 & 37.6 & 31.4 \\
\hline Protein content, \% & $3.21 \pm 0.03$ & $3.15 \pm 1.5$ & $3.18 \pm 0.02$ & $3.26 \pm 0.02$ \\
\hline Cv, \% & 1.6 & 3.2 & 3.5 & 2.8 \\
\hline Protein, $\mathrm{kg}$ & $211 \pm 9.6$ & $163 \pm 5.4$ & $179 \pm 11.5$ & $225 \pm 14.3$ \\
\hline $\mathrm{Cv}, \%$ & 31.3 & 22.7 & 38.5 & 31.1 \\
\hline
\end{tabular}


e. Konbeo Red DE 579810507, breeding farm «Kolos»

\begin{tabular}{|l|c|c|c|c|}
\hline \multicolumn{1}{|c|}{ Characteristic } & $\begin{array}{c}\text { High lactation } \\
(\mathrm{n}=68)\end{array}$ & $\begin{array}{c}\text { First lactation } \\
(\mathrm{n}=68)\end{array}$ & $\begin{array}{c}\text { Second lactation } \\
(\mathrm{n}=63)\end{array}$ & $\begin{array}{c}\text { Third lactation } \\
(\mathrm{n}=52)\end{array}$ \\
\hline Yield of milk, $\mathrm{kg} \mathrm{\kappa} \Gamma$ & $7524 \pm 126$ & $6611 \pm 129$ & $7006 \pm 152$ & $7266 \pm 122$ \\
\hline Cv, \% & 13.8 & 16.2 & 17.2 & 12.5 \\
\hline Fat content, \% & $3.79 \pm 0.010$ & $3.79 \pm 0.009$ & $3.79 \pm 0.009$ & $3.82 \pm 0.01$ \\
\hline Cv, \% & 2.2 & 2.0 & 1.9 & $278 \pm 5.00$ \\
\hline Fat, $\mathrm{kg}$ & $285 \pm 4.85$ & $250 \pm 4.67$ & $266 \pm 5.58$ & 12.9 \\
\hline Cv, \% & 14.1 & 15.5 & 16.8 & $3.18 \pm 0.01$ \\
\hline Protein content, \% & $3.18 \pm 0.006$ & $3.16 \pm 0.01$ & $3.16 \pm 0.006$ & 2.3 \\
\hline Cv, \% & 1.6 & 2.6 & 1.5 & $231 \pm 3.83$ \\
\hline Protein, $\mathrm{kg}$ & $238 \pm 3.92$ & $209 \pm 4.1$ & $222 \pm 4.64$ & 11.9 \\
\hline Cv, $\%$ & 13.6 & 16.4 & 16.6 & \\
\hline
\end{tabular}

f. Contemporaryes of the Konbeo Red DE 579810507 daughters

\begin{tabular}{|l|c|c|c|}
\hline \multicolumn{1}{|c|}{ Characteristic } & $\begin{array}{c}\text { First lactation } \\
(\mathrm{n}=116)\end{array}$ & $\begin{array}{c}\text { Second lactation } \\
(\mathrm{n}=106)\end{array}$ & $\begin{array}{c}\text { Third lactation } \\
(\mathrm{n}=41)\end{array}$ \\
\hline Yield of milk, $\mathrm{kg}$ & $6219 \pm 91$ & $6672 \pm 145$ & $7423 \pm 232$ \\
\hline Cv, \% & 15.8 & 22.5 & $3.78 \pm 0.009$ \\
\hline Fat content, \% & $3.75 \pm 0.008$ & $3.76 \pm 0.009$ & 1.5 \\
\hline Cv, \% & 2.3 & 2.4 & $281 \pm 8.70$ \\
\hline Fat, $\mathrm{kg}$ & $233 \pm 3.31$ & $251 \pm 6.33$ & $3.18 \pm 0.009$ \\
\hline Cv, $\%$ & 15.6 & 25.8 & 1.8 \\
\hline Protein content, \% & $3.12 \pm 0.009$ & $3.14 \pm 0.007$ & $236 \pm 7.32$ \\
\hline Cv, $\%$ & 3.1 & 2.3 & 19.8 \\
\hline Protein, $\mathrm{kg}$ & $194 \pm 2.6$ & $210 \pm 7.05$ & 21.4 \\
\hline Cv, $\%$ & 14.6 & & \\
\hline
\end{tabular}

The largest number of bulls of this related group (5 heads) ware used during 2006-2008 years in the breeding farm "Agroecology" of the Poltava region. By the content of fat in milk, the daughter of all bulls ware superior and the protein content corresponded to the standard of breed (table 3 ).

\section{Daughter's milkproductivity of bulls Leader related group in the breeding farm "Agroecology" during 305 days of}

\begin{tabular}{|l|c|c|c|c|c|c|c|c|c|}
\hline \multirow{2}{*}{$\begin{array}{c}\text { Name and num- } \\
\text { ber of bulls. } \\
\begin{array}{c}\text { Number of } \\
\text { daughters }\end{array}\end{array}$} & $\begin{array}{c}\text { yield } \\
\text { of } \\
\text { milk, } \\
\mathrm{kg}\end{array}$ & $\begin{array}{c}\text { First lactation } \\
\text { fat con- } \\
\text { tent, } \%\end{array}$ & $\begin{array}{c}\text { protein } \\
\text { con- } \\
\text { tent, } \%\end{array}$ & $\begin{array}{c}\text { yield } \\
\text { of } \\
\text { milk, } \\
\mathrm{kg}\end{array}$ & $\begin{array}{c}\text { Second lactation } \\
\text { tent, } \%\end{array}$ & $\begin{array}{c}\text { Third lactation } \\
\text { protein } \\
\text { tent, } \%\end{array}$ & $\begin{array}{c}\text { yield } \\
\text { of } \\
\text { milk, } \\
\text { kg }\end{array}$ & $\begin{array}{c}\text { Tat con- } \\
\text { tent, } \%\end{array}$ & $\begin{array}{c}\text { pon- } \\
\text { protein } \\
\text { tent, } \%\end{array}$ \\
\hline $\begin{array}{l}\text { Kompas } \\
5788802, \\
\mathrm{n}=46\end{array}$ & 5697 & 3.87 & 3.30 & 7045 & 3.90 & 3.28 & 6992 & 3.89 & 3.27 \\
\hline $\begin{array}{l}\text { Flame 3002008, } \\
\mathrm{n}=27\end{array}$ & 5913 & 3.86 & 3.28 & 6907 & 3.91 & 3.28 & 6735 & 3.89 & 3.28 \\
\hline $\begin{array}{l}\text { Kanzler } \\
8305280, \\
\mathrm{n}=45\end{array}$ & 5591 & 3.87 & 3.23 & 6351 & 3.88 & 3.25 & 6880 & 3.76 & 3.16 \\
\hline $\begin{array}{l}\text { Rubinrot } \\
9530275, \mathrm{n}=29\end{array}$ & 6132 & 3.83 & 3.28 & 6346 & 3.81 & 3.22 & 6817 & 3.83 & 3.23 \\
\hline $\begin{array}{l}\text { Kadenz } \\
4151975 \\
\mathrm{n}=34\end{array}$ & 5922 & 3.96 & 3.32 & 6640 & 3.98 & 3.32 & 7070 & 3.88 & 3.31 \\
\hline
\end{tabular}


The economic efficiency of using the bulls-improvers of the complex traits of the related Leader's 1926780 group was determined by the indicators of their primary breeding value with a rank of repeatability of $85 \%$ and above. It was determined that, it dependent from the level of the breeding value of the bull and the number of received daughters and varied from 223.2 (bull Kurgan Red 836267, CBV'15) to 1361.8 thousand UAH (Rubinrot Red 530275 ZW'09).

Conclusions. It was established that the bulls of foreign selection of related Leader 1926780 group, which are used in breeding herds of Ukrainian red and white dairy breed, kept the breeding value of a complex milk productivity traits at a positive level during 8-11 years and consistently passed theirs to offsprings of domestic breeding.

According to the number of livestock, the genealogical structure, the level of influence on the consolidation of the breed by the complex of traits of milk production as yield of milk, the content of fat and protein in milk, the animals of this related group deserve the wide using in the breeding enterprises of the Ukrainian red and white dairy breed and the creation, on their basis, a generalbreed bloodline with high content of protein and fat in milk.

\section{BIBLIOGRAPHY}

1. Програма удосконалення та організації ведення селекційного процесу в українській червоно-рябій молочній породі великої рогатої худоби на перспективу до 2020 року / А. А. Гетя, Н. В. Кудрявська, О. І. Костенко, М. І. Бащенко, С. Ю. Рубан, О. Д. Бірюкова, Г. С. Коваленко, В. П. Шабля, В. О. Даншин, П. І. Шаран, С. В. Кузебний, Д. М. Басовський, Н. В. Швець, Т. О. Кругляк, Г. О. Гольоса, А. П. Кругляк, С. І. Терехов. - Чубинське, 2013. - 59 с.

2. Українська червоно-ряба молочна порода - результат реалізації нової теорії у скотарстві / А. П. Кругляк, О. Д. Бірюкова, Г. С. Коваленко, Т. О. Кругляк // Розведення і генетика тварин. - К., 2015. - Вип. 50. - С. 39-48.

3. Кругляк А. П. Перспективна споріднена група бугая Лідера в українській червоно-рябій молочній породі / А. П. Кругляк, Т. О. Кругляк // Тваринництво України. - 2013. - № 1-2. C. 20-24.

4. Українська червоно-ряба молочна порода / М. І. Бащенко, Ю. Ф. Мельник, А. П. Кругляк та ін. // Селекційні, генетичні та біотехнологічні методи удосконалення і збереження генофонду сільськогосподарських тварин. - Полтава : ТОВ «Фірма Техсервіс». - 2018. - С. 209-252.

5. Положення з проведення апробації селекційних досягнень у тваринництві : за тв. наказом мін-ва аграр. політики та прод-ва України від 02.07.2012 № 385. - К., 2012. - 17 с.

6. Стандартизація у тваринництві / I. І. Ібатуллін, В. О. Пабат, А. Я. Маньковський та ін. Київ. - Видавництво Ліра - К. - 2017. - 548 с.

7. Боровиков, В. STATISTICA : искусство анализа данных на компьютере. Для профессионалов / В. Боровиков // СПб : Питер, 2001. - 656 с.

\section{REFERENCES}

1. Getya, A. A., N. V. Kudryavs`ka, O. V. Kostenko, M. I. Bashchenko, S. Yu. Ruban, O. D. Biryukova, G. S. Kovalenko, V. P. Shablya, V. O. Danshyn, P. I. Sharan, S. V. Kuzebnyi, D. N. Basovskyi, N. V. Shvets, T. O. Krugliak, G. O. Golyesa, A. P. Krugliak, S. I. Terechov. 2013. Programa udoskonalennya ta organizaciyi vedennya selekcijnogo procesu v ukrayins kij chervono-ryabij molochnij porodi vely koyi rogatoyi khudoby na perspektyvu do 2020 roku - Program for improvement and organization of breeding process in Ukrainian red-white dairy cattle for the perspective up to 2020 year. - Chubynske, 59 (in Ukrainian).

2. Kruglyak, A. P., O. D. Biryukova, G. S. Kovalenko, T. O. Kruglyak. 2015. Ukrayins 'ka chervono-ryaba molochna poroda - rezul tat realizaciyi novoyi teoriyi u skotarstvi - Ukrainian red-andwhite dairy breed is the result of a new theory of cattle breeding. Rozvedennya i henetyka tvarynAnimal Breeding and Genetics. 50:39-48 (in Ukrainian).

3. Kruglyak, A. P., Kruglyak, T. O. 2013. Perspektyvna sporidnena grupa buhaia Lidera V ukrayins ` kij chervono-ryabij molochnij porodi. - Promising related group of the Leader in Ukrainian 
red and white dairy breed. Tvarynnystvo Ukrayiny - Animal Husbandry of Ukraine. 1 - 2:20-24 (in Ukrainian).

4. Bashchenko, M. I., Yu. F. Mel`nyk, A. P. Kruglyak, O. D. Birykova, Yu. P. Polupan, T. O. Krugliak. 2018. Ukrayins 'ka chervono-ryaba molochna poroda - Ukrainian red and white dairy breed. Selekcijni, genetychni ta biotexnologichni metody udoskonalennya i zberigannya genofondu sil's 'kogospodars 'kykh tvaryn - Breeding, genetic and biotechnological methods for the improvement and preservation breed's gene-found of farm animals (in Ukrainian).

5. Polozhennya z provedennia aprobaciyi selekcijnykh dosyagnen ' u tvarynnycztvi-Regulations on approbation of breeding achievements in livestock breeding. - Kyiv, 19 ly'pnya 2012. 1217/21529. - 17.

6. Ibatullin, I. I., V. O. Pabat, A. Ya. Man`kovs `ky`j ta in. 2017. Standartyzaciya u tvarynnycztvi - Standardization in animal husbandry. Kyiv, Vydavnycztvo Lira - Ka, 5-11 (in Ukrainian).

7. Borovikov, V. 2001. STATISTICA: Iskusstvo analiza dannykh na komp'jutere: dlya professionalov - STATISTICS: Art of computer data analysis: for professionals. S. Peterburg, 656 (in Russian). 